Article

\title{
Experimental Performance of an Advanced Air-Type Photovoltaic/Thermal (PVT) Collector with Direct Expansion Air Handling Unit (AHU)
}

\author{
Jin-Hee Kim ${ }^{1}{ }^{1}$, Sang-Myung Kim ${ }^{2}{ }^{\circledR}$ and Jun-Tae Kim ${ }^{3, *}$ \\ 1 Green Energy Technology Research Center, Kongju National University, Cheonan 314701, Korea; \\ jiny@kongju.ac.kr \\ 2 Graduate School of Energy System Engineering, Kongju National University, Cheonan 314701, Korea; \\ mtanzania@smail.kongju.ac.kr \\ 3 Department of Architectural Engineering, Kongju National University, Cheonan 314701, Korea \\ * Correspondence: jtkim@kongju.ac.kr; Tel.: +82-41-521-9333
}

Citation: Kim, J.-H.; Kim, S.-M.; Kim, J.-T. Experimental Performance of an Advanced Air-Type

Photovoltaic/Thermal (PVT)

Collector with Direct Expansion Air Handling Unit (AHU). Sustainability 2021, 13, 888. https://doi.org/ su13020888

Received: 2 December 2020 Accepted: 14 January 2021 Published: 17 January 2021

Publisher's Note: MDPI stays neutral with regard to jurisdictional clai$\mathrm{ms}$ in published maps and institutional affiliations.

Copyright: $\odot 2021$ by the authors. Licensee MDPI, Basel, Switzerland. This article is an open access article distributed under the terms and conditions of the Creative Commons Attribution (CC BY) license (https:// creativecommons.org/licenses/by/ $4.0 /)$.

\begin{abstract}
In addition to electrical energy generation, photovoltaic/thermal (PVT) systems utilize heat from building-integrated photovoltaic (BIPV) modules for domestic hot water and space heating. In other words, a PVT system can improve the electricity efficiency of BIPVs while using the waste heat of BIPVs as a source of thermal energy for the building. By generating thermal and electrical energies simultaneously, PVT systems can improve the utilization of solar energy while enhancing the energy performance of buildings. To optimize the performance of an air-type PVT collector, it is necessary for the system to extract more heat from the PV module. Consequently, this approach decreases PV temperature to improve PV electrical energy generation. The thermal and electrical performance of an air-type PVT collector depends on its design, which affects airflow and heat transfer. Moreover, the performances of the PVT collector can differ according to the coupled facility in the building. In this study, the thermal and electrical performances of an advanced air-type PVT collector with a direct expansion air handling unit (AHU) were analyzed experimentally. For this purpose, six prototypes of an advanced air-type PVT collector were developed. Furthermore, a direct expansion AHU with a heat recovery exchanger (HRX) was designed and built. The advanced PVT collectors with a total capacity of $740 \mathrm{Wp}$ were installed in an experimental house and were coupled to the direct expansion AHU system with a maximum airflow of $700 \mathrm{CMH}$. The performance of PVT collectors was analyzed and compared with the BIPV system. Results showed that buildingintegrated photovoltaic/thermal (BIPVT) collectors produced $30 \mathrm{~W}$ more power than the BIPV system. When operating the AHU system, the temperature of the BIPVT collector was generally lower than the BIPV. The maximum difference in temperature between BIPVT and BIPV was about $22{ }^{\circ} \mathrm{C}$. During winter season, the BIPVT collector supplied preheated air to the AHU. The supplied air temperature from the BIPVT collector reached $32{ }^{\circ} \mathrm{C}$, which was $15{ }^{\circ} \mathrm{C}$ higher than outdoor air temperature.
\end{abstract}

Keywords: BIPVT (building-integrated photovoltaic/thermal); air-type PVT collector; AHU (air handling unit); mock-up experiment; thermal and electrical efficiency

\section{Introduction}

One of the biggest problems of a building-integrated photovoltaic (BIPV) system is the degradation of photovoltaic (PV) module efficiency. The efficiency of the PV module decreases by about $0.4-0.5 \%$ when the temperature of the PV module rises by $1{ }^{\circ} \mathrm{C}$ at a PV module temperature of $25^{\circ} \mathrm{C}$ [1]. To solve BIPV power loss due to PV temperature rise, a building-integrated photovoltaic/thermal (BIPVT) system has been developed.

The BIPVT system is one of the solar energy systems that produce electricity and heat simultaneously. The PV module of the PVT system produces electricity, and the heat 
generated from the PV module can be used as a heat source for heating and domestic hot water (DHW) in buildings. By using heat from the PV module as a heat source for the building, the PVT system can prevent the rise of PV module temperature and the related power degradation [2,3]. Kazem et al. [4] conducted an outdoor test of three water cooling PVT systems that had variable flow channels (web type, direct type, spiral type) and compared them with conventional PVs in terms of electrical performance. In their results, the proposed PVT systems reduced the PV cell temperature by an average of $3{ }^{\circ} \mathrm{C}$. The electrical efficiencies of the PVT systems were higher than conventional PVs. The conventional PV module had an electrical efficiency of about $7.8 \%$, while the highest achieved PVT electrical efficiency was found to be $9.1 \%$ for a spiral flow collector.

BIPVT systems can be categorized into air type, liquid type, and hybrid type, depending on the heat transfer medium used. BIPVT, which uses air as a heat medium, has an advantage of being the easiest to apply and maintain in building systems. The performance of the air-type PVT system is affected by a number of factors such as airflow, flowrate, absorber configuration, baffle shape and arrangement, and so on. Bakari [5] conducted an experiment to analyze the effect of different numbers of baffles. In the study, air solar collectors that were integrated with $2,3,4$, and 8 baffles were evaluated and compared with a conventional flat plate collector. The results showed that the collector with 2, 3, 4, and 8 baffles had an efficiency of $29.2 \%, 31.3 \%, 33.1 \%$, and $33.7 \%$ respectively, whereas the efficiency of the air collector without baffle was $28.9 \%$. Furthermore, the impact of the shape and arrangement of baffles and absorption plates on air-type PVT performance has been evaluated through experimental and numerical analyses [6-9].

In addition to baffles and absorber plates, some studies have presented various factors that affect the performance of the PVT system such as nanoparticles, PCM, and coolant. Many researchers have shown that the efficiency of the PVT system can be improved by using metallic nanoparticles together with a PCM. In addition, some results showed that the thermal performance of the coolant is one of the key elements that has potential to improve the PVT system $[10,11]$. Various related studies have focused on the application of PVT systems together with building facilities. Boutina et al. [12] studied an air-type PVT collector integrated with a chimney tower, and the effects were analyzed through CFD simulation. The proposed PVT collector improved heat transfer rate by approximately 78\% over conventional air-type PVT collectors. Tiwari et al. [13] designed and tested a greenhouse dryer using heat sources from an air-type PVT collector. The thermal efficiency, electrical efficiency, and overall thermal efficiency of the air-type PVT collector were found to be $26.68 \%, 11.26 \%$, and $56.30 \%$, respectively. In addition, the air-powered PVT collectors were approximately twice as cheap as electric dryers. Fan et al. [14] proposed an airconditioned PVT-SAH (solar air heater) model with heat pipes. The payback period of the proposed system was evaluated at be 5.7 to 16.8 years. The thermal efficiency of the system was $12 \%$ higher, and it was found that the temperature of the PV module decreased effectively. In a previous study, Kim et al. [15] studied the energy performance of a building's heating system combined with BIPVT collectors that used water as a heat medium. For their study, a water-type unglazed BIPVT collector was developed and installed on the roof of an experimental house; it was then combined with a heating system consisting of a thermal storage tank, an auxiliary boiler, an inverter, and a fan-coil unit in order to use the thermal energy of PVT collectors. Results confirmed the thermal and electrical efficiencies of BIPVT collectors to be $30 \%$ and $17 \%$, respectively. In particular, the electrical efficiency showed a high performance of more than $16 \%$ when the heating system was running. The BIPVT increased the water temperature in the thermal storage tank by $40{ }^{\circ} \mathrm{C}$, and thus it can be utilized as a heat source for heating.

Aside from the energy saving potential, connecting an air handling unit (AHU) system to an air-type PVT collector can help improve the performance of the AHU systems. Especially during the winter season when very cold outdoor air enters the AHU system directly, damages to the AHU equipment can occur. However, the connection between the BIPVT system and the AHU can protect the AHU system by using warmer air through 
PVT collectors instead of the outdoor cold air directly. Moreover, the use of the warmed air can reduce the energy used to heat the cold outdoor air.

In this study, the performance of air-based BIPVT collectors that are connected to an AHU system in the experimental building is evaluated. Firstly, the electrical performance and the temperature characteristics of the developed BIPVT collector are evaluated by an outdoor test. To compare the performance of the BIPVT collector, the BIPV system is manufactured and tested together. The electrical and thermal characteristics of the BIPVT collector and the BIPV system are analyzed. After this, the performance of the AHU system with BIPVT is evaluated. The temperature characteristics of the BIPVT collector is analyzed through operating the AHU system. In addition, with the AHU system connected to the air-type BIPVT collector, the energy saving potential of the building can also be analyzed.

\section{Experimental House of the AHU System with BIPVT Collector}

For this study, an air-type PVT collector was designed, as shown in Figure 1. In previous studies, the PVT collectors were developed using conventional PV modules with little gap between PV cells [1-3,11,12]. For this study, the developed PVT collector was integrated with a glass-to-glass PV module, and the PV module was designed to keep a constant gap between PV cells to improve the thermal performance of the PVT collector. The spacing between PV cells allows more solar heat to enter the collector than conventional collectors. Moreover, below the gaps, the absorber plates which have high thermal conductivity were installed. Absorber plates that have high thermal conductivity is one of the main parameters affecting the thermal performance of PVT system [16,17]. By placing the absorber plate below the space between PV cells, the temperature inside the collector can be increased by directly transferring the solar heat to the absorber plate. The installed absorber plates have a round bending shape, and they works as internal baffles that can improve heat collecting efficiency [18]. When air passes through the PVT collector from the inlet to the outlet, the absorber plates lengthen the airflow pathway and create turbulence inside the collector. The lengthened air pathway and turbulence both help to increase heat transfer and improve the thermal performance of the PVT collectors [19].

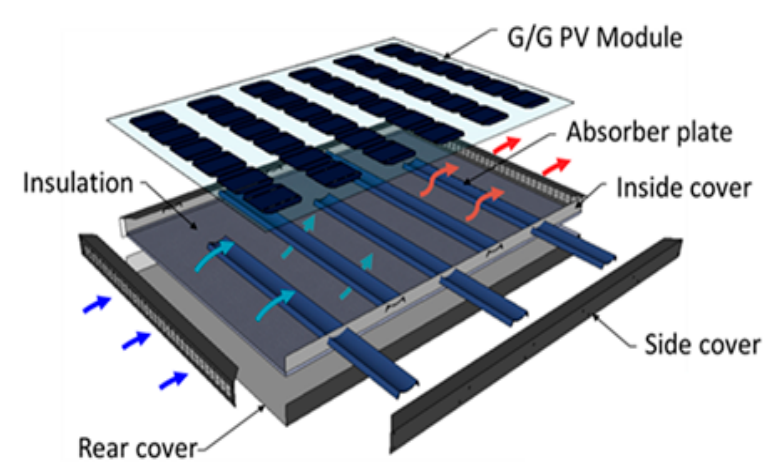

(a)

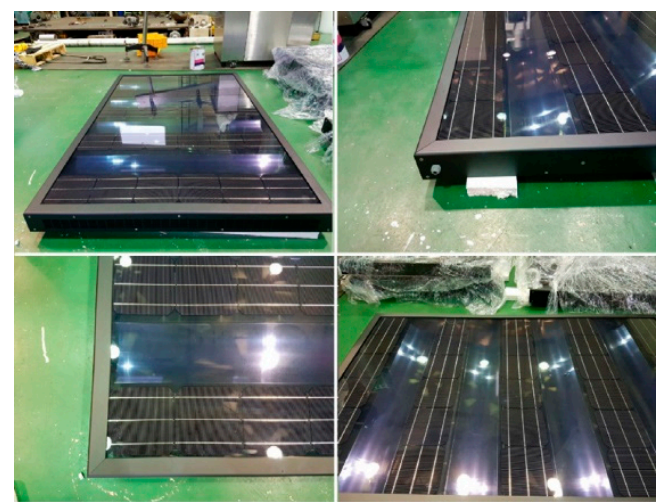

(b)

Figure 1. Designed air-type photovoltaic/thermal (PVT) collector: (a) Schematic diagram; (b) Prototype of the PVT collector.

The designed BIPVT collectors were connected to a direct expansion air handling unit (AHU) and installed in an experimental house. Figure 2 shows the experimental house and the connection of BIPVT collectors and the AHU system. Six BIPVT collectors were installed on the south side; the BIPVT collectors, top and bottom, were connected as one set. Outdoor air enters the inlet below the BIPVT collectors and then is heated by passing through the BIPVT collectors. 


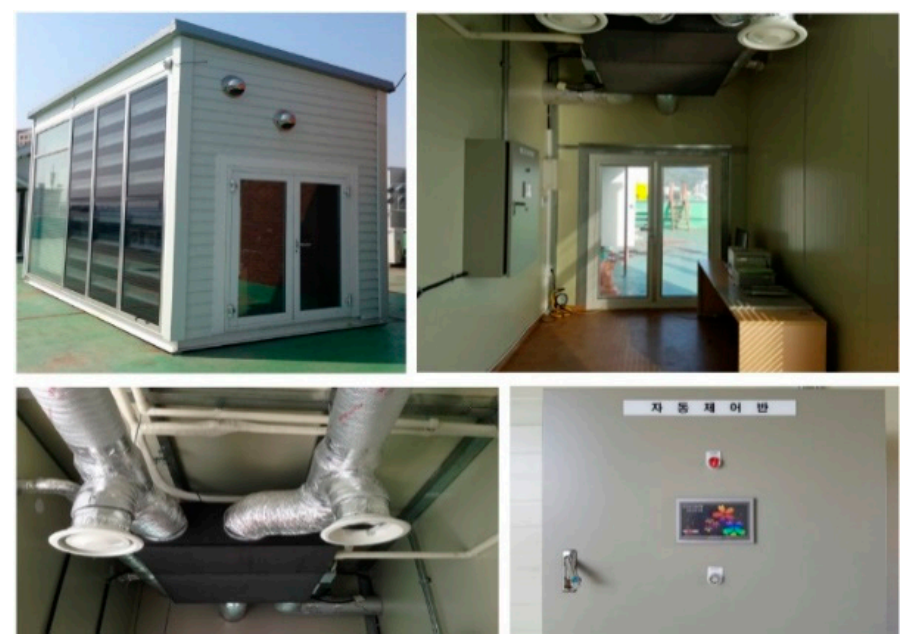

(a)

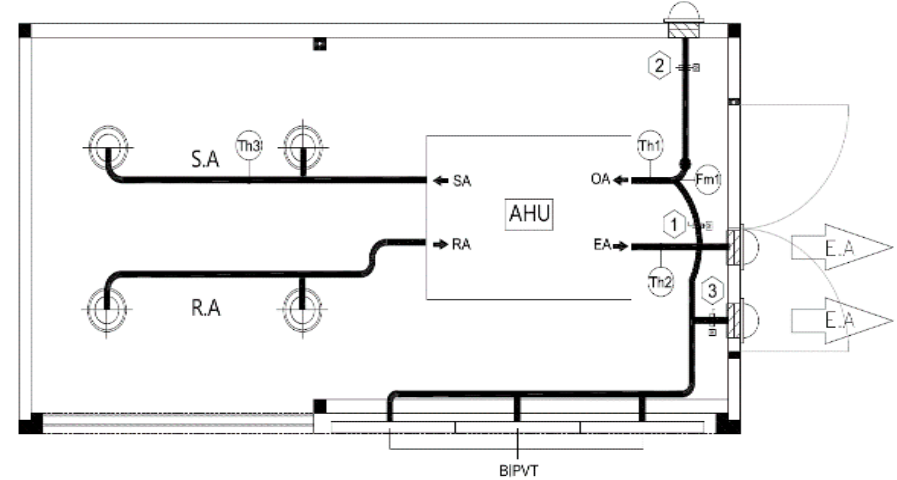

(b)

Figure 2. Experimental house: (a) Experimental house and equipment system; (b) Schematic diagram of the air handling unit (AHU) system with building-integrated photovoltaic/thermal (BIPVT) collectors.

\section{Experimental Setup}

For the analysis, the BIPVT collectors were evaluated on two bases. One focus is on the BIPVT collector side, and the other one concerns the overall system of the AHU with BIPVT collectors. First, the performance of the BIPVT collector was compared with the BIPV system. Then, the energy savings of the AHU system with the BIPVT collector was investigated. The experiment was evaluated in Cheonan, Republic of Korea $\left(36.815^{\circ} \mathrm{N}\right.$, $\left.127.114^{\circ} \mathrm{E}\right)$.

\subsection{Comparison of BIPVT and BIPV System}

In order to analyze the performance of the BIPVT collector, a BIPV system was made as shown in Figure 3. The BIPV system was composed of an insulation behind the PV module to satisfy the performance of the building exterior wall. The temperature of the PV module was measured by thermocouples, and the temperature characteristics of the BIPVT and BIPV system were analyzed. 

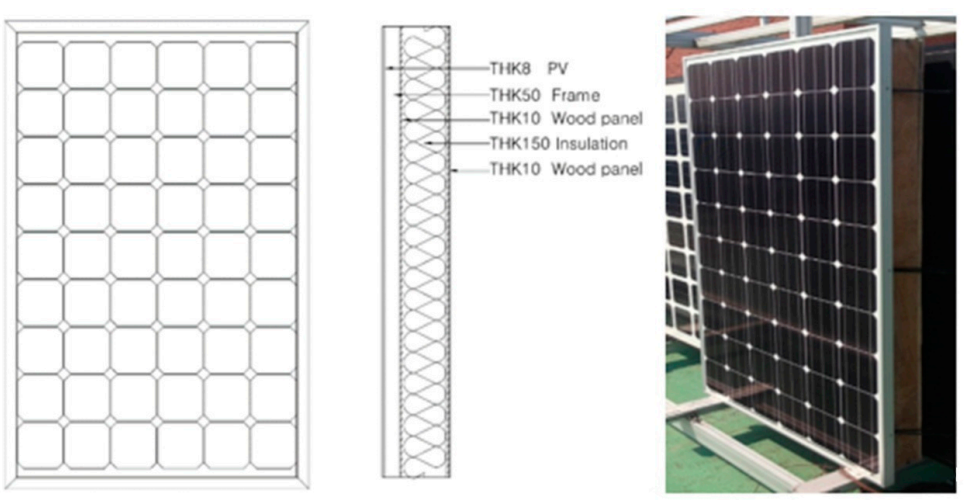

(a)
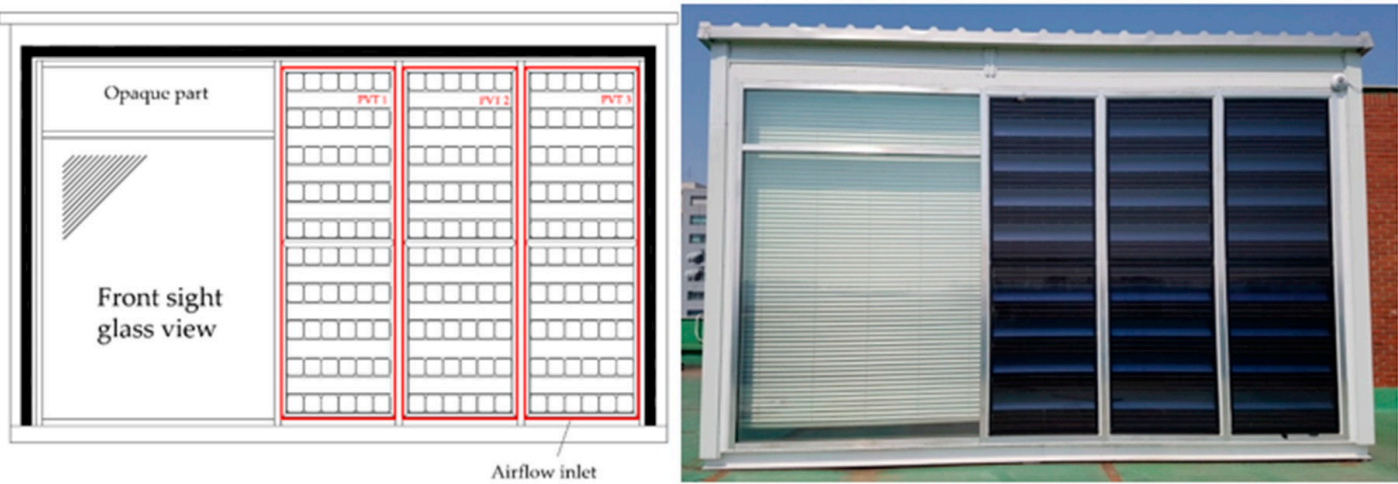

(b)

Figure 3. Experimental house: (a) BIPV system; (b) Experimental house with BIPVT system.

The specification of the PV modules are summarized in Table 1. For the experimental measurements, the associated sensitivity and inaccuracy of measuring equipment should be considered. In this experiment, the uncertainties of the measuring devices were considered. The detailed specification of measuring instruments including uncertainties is presented in Table 2.

Table 1. Specification of the PV module for the BIPVT collector and the BIPV system.

\begin{tabular}{ccc}
\hline Specification & BIPVT Module & BIPV Module \\
\hline PV cell type & \multicolumn{2}{c}{ Mono-crystalline silicon } \\
PV module efficiency & $7.6 \%$ & $16.2 \%$ \\
Maximum power & $123.3 \mathrm{~W}$ & $265.08 \mathrm{~W}$ \\
Maximum voltage & $15.08 \mathrm{~V}$ & $31.01 \mathrm{~V}$ \\
Maximum current & $8.18 \mathrm{~A}$ & $8.55 \mathrm{~A}$ \\
Open circuit voltage $\left(\mathrm{V}_{\mathrm{oc}}\right)$ & $19.05 \mathrm{~V}$ & $38.53 \mathrm{~V}$ \\
Short circuit current $\left(\mathrm{I}_{\mathrm{sc}}\right)$ & $8.61 \mathrm{~A}$ & $9.05 \mathrm{~A}$ \\
Collector size & $1584 \times 1031 \times 84.5 \mathrm{~mm}$ & $1084 \times 1031 \times 84.35 \mathrm{~mm}$
\end{tabular}

Table 2. The range and accuracy of the measuring instrument.

\begin{tabular}{ccc}
\hline Description & Measurement Range & Accuracy \\
\hline Humidity and temperature & -50 to $100{ }^{\circ} \mathrm{C}$ & $\pm 0.8 \% \mathrm{RH}$ at $23^{\circ} \mathrm{C}$ \\
transmitter & 0 to $100 \% \mathrm{RH}$ & $\pm 0.1 \mathrm{~K}$ at $23^{\circ} \mathrm{C}$ \\
Pyranometer (nonlinearity) & 0 to $2000 \mathrm{~W} / \mathrm{m}^{2}$ & $\pm 1.2 \%$ at $<1000 \mathrm{~W} / \mathrm{m}^{2}$ \\
Thermocouple & -250 to $500{ }^{\circ} \mathrm{C}$ & $\pm 0.5{ }^{\circ} \mathrm{C}$ \\
Power meter & $15-600 \mathrm{~V}$ & $0.1 \%$ of the reading \\
Data logger & $0.5-20 \mathrm{~A}$ & $0.1 \%$ of the range \\
\hline
\end{tabular}




\subsection{AHU System with BIPVT Collectors}

BIPVT collectors that were installed in the experimental building were connected to the AHU system. The heated air through the BIPVT collectors passed through the outlet and entered the supply air channel of the AHU. It was controlled with a fan and a damper, and there are two operation modes as shown in Figure 4. When the heating for space is not required, such as during summer season, the damper is closed in order to block the channel between the PVT collector and the AHU, and the heated air is exited outdoors. This prevents overheating of the PV module, which can also improve the electrical efficiency of the PV module by decreasing the temperature of the PV module in summer. During winter when heating is required, the damper is opened to allow the heated air to enter into the AHU as supply air. By using the warmed air as supply air for the AHU, the energy needed to heat the cold outdoor air in the AHU system can be reduced. In order to analyze the energy savings for the AHU system, a test was conducted in the heating season. For the test, the temperature of the PVT collector outlet, the supply air temperature for the room, and the outdoor air temperature were measured.

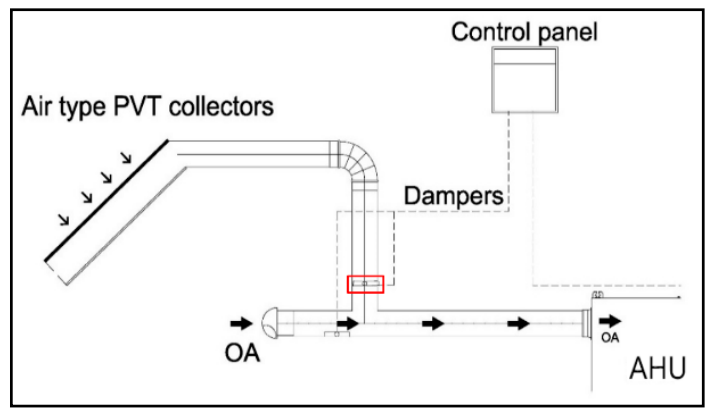

(a)

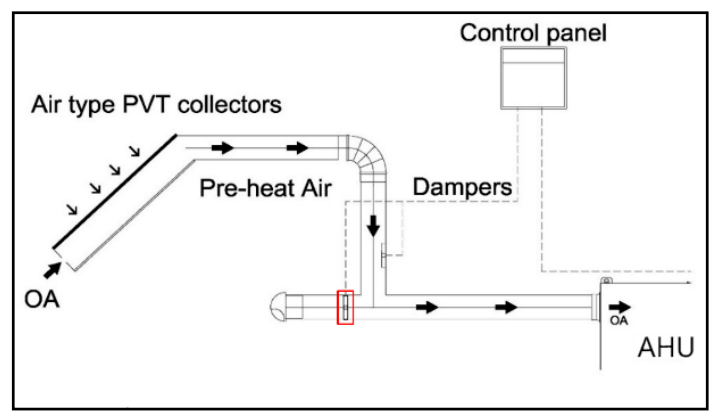

(b)

Figure 4. Operation mode of the AHU system with PVT collectors: (a) Nonheating season; (b) Heating season.

\section{Results and Discussions}

The experimental data were collected in the heating period from February to March. When the BIPVT and BIPV system were compared, the heated air of the BIPVT collector was extracted outdoors. During the experiment of the AHU system with the BIPVT collector, the AHU system with the BIPVT collector was run in heating mode. The air heated by BIPVT collectors was fed into the outdoor air (OA) channel of the AHU unit instead of the cold outdoor air.

\subsection{Comparison of Performance with the BIPVT and BIPV Systems}

The daily electricity yield of the BIPVT collector and the BIPV is shown in Figure 5. When solar radiation was lower than $600 \mathrm{~W} / \mathrm{m}^{2}$, the PV power of the BIPV was higher than the BIPVT collector. However, when solar radiation increased to more than $600 \mathrm{~W} / \mathrm{m}^{2}$, the PV power of the PVT increased more than that of the BIPV. In particular, it was found that during the highest solar radiation around midday (12-2 pm), the difference in PV power generation between BIPVT and BIPV was the largest.

The reason for the difference in PV power between the BIPV system and the BIPVT collectors can be explained with reference to Figure 6. Figure 6 graphically compares the average temperature of the PV module in the BIPV and BIPVT systems. The graph shows that the PV module temperature fluctuated according to changes in solar radiation. The PV module temperatures increased as the solar radiation increased. The PV module temperature of both the BIPVT and BIPV system increased according to increasing solar radiation, but the PV module temperature of the BIPVT collector was lower than that of the BIPV. The temperature of the BIPV was within a range of $15-58{ }^{\circ} \mathrm{C}$ for one day, and that for the BIPVT collectors ranged between 12 and $41.8^{\circ} \mathrm{C}$. The lower PV temperature of 
the BIPVT system was attributed to the exiting heat with air; this can help to prevent degradation of PV power generation caused by temperature increase of the PV module.

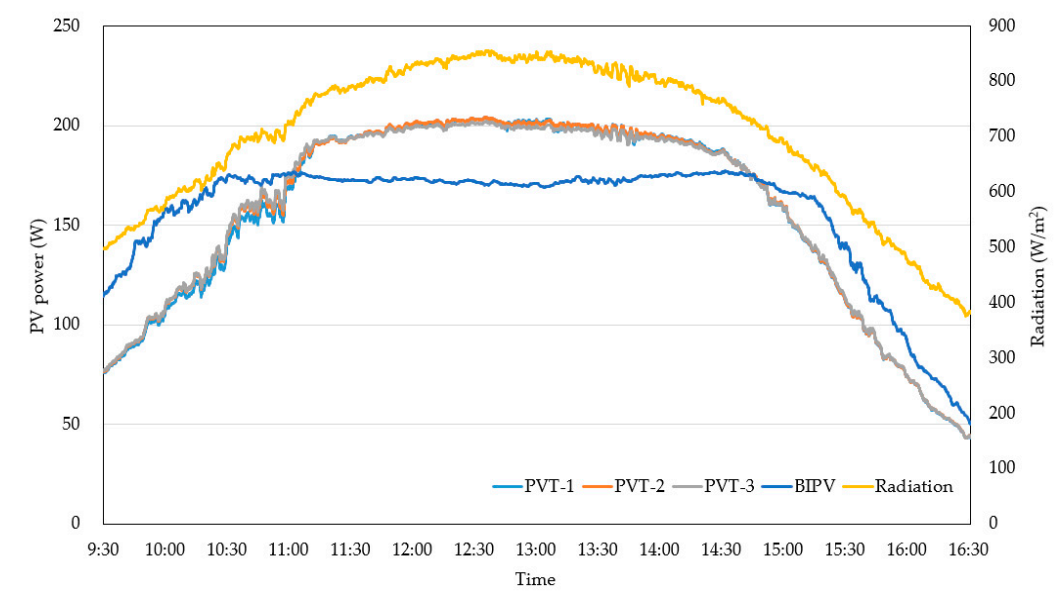

Figure 5. Daily PV power generation of the BIPV and BIPVT collector.

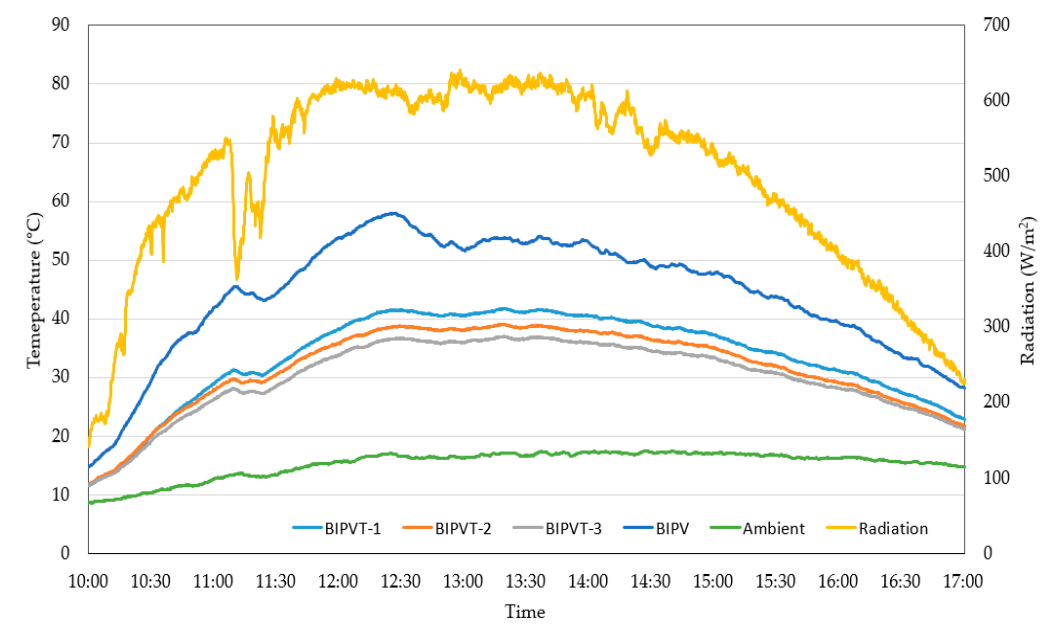

Figure 6. Effect of time on PV temperature and solar radiation on the BIPVT and BIPV systems.

Figure 7 compares the electrical efficiency of the PV module in the BIPV and BIPVT systems. The efficiency was calculated by Equation (1) [20]:

$$
\eta_{e f f}=\frac{V \times I}{A_{p v} \times G}
$$

where $\eta_{e f f}, V, I, A_{p v}$, and $G$ are the electricity efficiency, the maximum voltage $(\mathrm{V})$, the maximum current (A), the PV area $\left(\mathrm{m}^{2}\right)$, and the global solar radiation $\left(\mathrm{W} / \mathrm{m}^{2}\right)$, respectively. In the case of the BIPV system, when solar radiation increased to more than $600 \mathrm{~W} / \mathrm{m}^{2}$, the electrical efficiency decreased. This was due to increasing the PV module temperature concurrently with high solar radiation. However, for the PVT system, even though solar radiation increased, the electrical efficiency was kept steady without degradation.

\subsection{AHU System with BIPVT Collector}

Figure 8a shows the temperature of the BIPVT collector and the BIPVT outlet. The outlet temperature of the BIPVT outlet was similar to the midrange temperature of the BIPVT collector. The PV module temperature of the PVT collector was about $25-40{ }^{\circ} \mathrm{C}$, depending on the changes in solar radiation. In addition, the extraction temperature preheated through the BIPVT collector was $22-38^{\circ} \mathrm{C}$, which was $10-20^{\circ} \mathrm{C}$ higher than the outside temperature. In Figure $8 \mathbf{b}$, when the temperature of the supply air delivered to the room 
through the AHU system was about $40{ }^{\circ} \mathrm{C}$, the temperature of outlet air from the BIPVT collector was about $32{ }^{\circ} \mathrm{C}$. When the outlet temperature was $32{ }^{\circ} \mathrm{C}$, the outdoor temperature was $17^{\circ} \mathrm{C}$, which was lower by $15^{\circ} \mathrm{C}$ compared to the supplied air from the BIPVT. In the existing AHU system, the cold outdoor air (OA) entered the AHU unit, then it was heated to supply the warm air for the room. By connecting the BIPVT collector with the AHU system, the preheated air from the BIPVT collector can be supplied. It was found that the heating energy of the AHU system was saved by using the BIPVT collector.

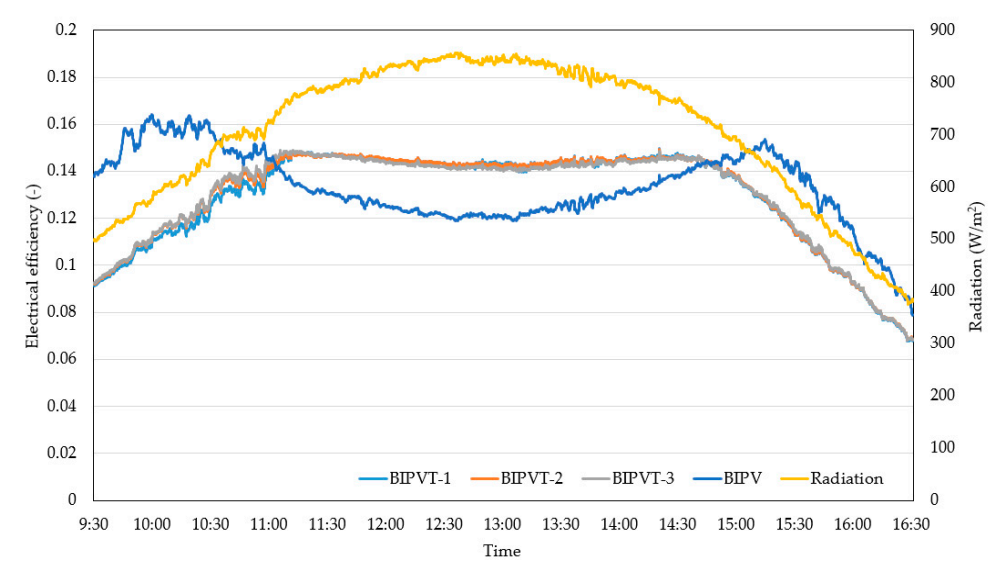

Figure 7. Effect of time on PV temperature and solar radiation on the BIPVT and BIPV systems.

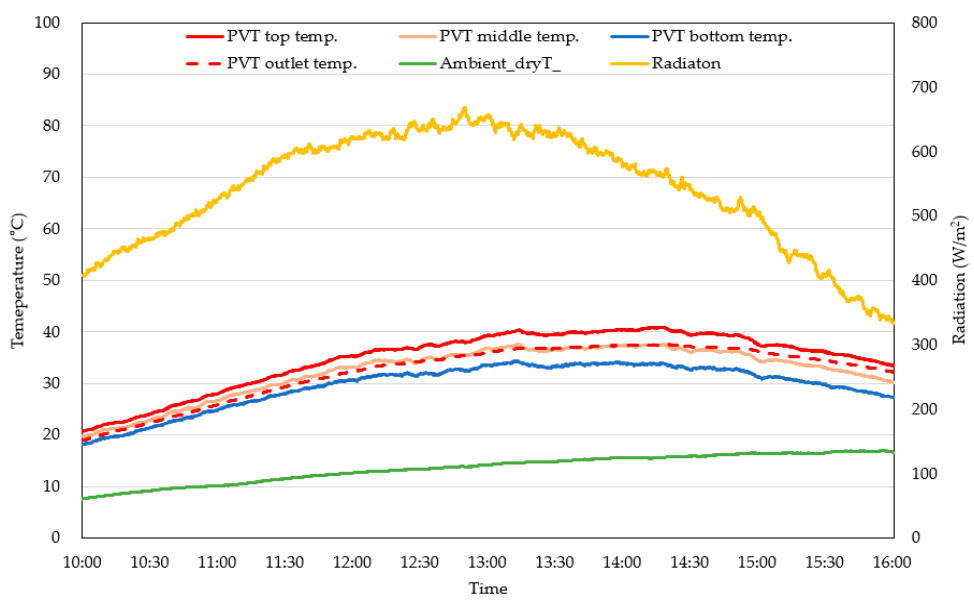

(a)

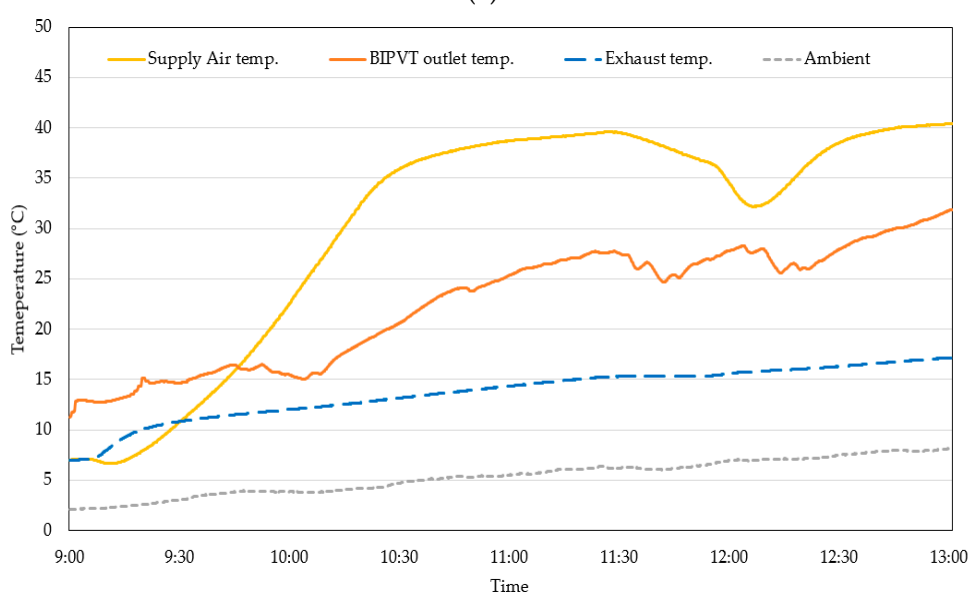

(b)

Figure 8. Operation mode of the AHU system: (a) Nonheating season; (b) Heating season. 


\section{Conclusions}

In this study, an air-type BIPVT collector was manufactured and installed in a realscale experimental house, and its electrical performance and temperature characteristics were investigated and compared with a BIPV system through experiments. In addition, the effect of energy savings was analyzed when the BIPVT was connected to an AHU system. The key findings are as follows:

(1) The air-type BIPVT collector can prevent the degradation of PV power generation that is often caused by increasing PV temperature. During experimental tests, the BIPVT collector produced electrical energy of about $200 \mathrm{~W}$ when the solar radiation was more than $800 \mathrm{~W} / \mathrm{m}^{2}$, which was $30 \mathrm{~W}$ more than the total electrical energy produced by the BIPV system. Moreover, the BIPVT collector was kept at a lower PV temperature than the BIPV, where the maximum difference of PV module temperature was about $22^{\circ} \mathrm{C}$.

(2) Air-type BIPVT collectors were found to maintain electrical efficiency even when solar radiation increased. During midday when solar radiation was the highest, PV electrical efficiency of the BIPV decreased up to $12 \%$ due to an increased PV module temperature. However, the electrical efficiency of BIPVT was steady at $14 \%$.

(3) Through tests in the experimental building, it was found that the connection of the BIPVT collector with the AHU system can save energy for heating. In the heating period, BIPVT collectors can supply preheated air to the AHU unit, and the AHU system can save energy to heat the cold outdoor air. The temperature of the preheated air from the BIPVT collector was $32{ }^{\circ} \mathrm{C}$, which was $15^{\circ} \mathrm{C}$ higher than the outdoor air.

Based on these results, the performance of the BIPVT collector and related energysaving effect by connecting to an AHU system in the building can be seen. It is expected that this study can be used as a foundation for further study on building systems integrated with BIPVT collectors.

Author Contributions: Conceptualization, J.-H.K., and S.-M.K.; methodology, J.-H.K.; software, S.-M.K.; validation, J.-H.K. and J.-T.K.; formal analysis, J.-H.K. and S.-M.K.; investigation, J.-H.K.; resources, S.-M.K.; data curation, J.-H.K.; writing-original draft preparation, J.-H.K. and S.-M.K.; writing-review and editing, J.-H.K., J.-T.K. and S.-M.K.; visualization, J.-H.K. and S.-M.K.; supervision, J.-T.K.; project administration, J.-H.K.; funding acquisition, J.-T.K. and J.-H.K. All authors have read and agreed to the published version of the manuscript.

Funding: This research was funded by Basic Science Research Program through the National Research Foundation of Korea (NRF) funded by the Ministry of Education (NRF-2018R1D1A1A09083870) and Korea Institute of Energy Technology Evaluation and Planning (KETEP) and the Ministry of Trade, Industry and Energy (MOTIE) of the Republic of Korea, grant number 20188550000480.

Institutional Review Board Statement: Not applicable.

Informed Consent Statement: Not applicable.

Data Availability Statement: Not applicable.

Acknowledgments: The authors would like to thank Natural Resources Canada for their contribution to preliminary stages of the project.

Conflicts of Interest: The authors declare no conflict of interest.

\section{References}

1. Sathe, T.M.; Dhoble, A.S. A review on recent advancements in photovoltaic thermal techniques. Renew. Sustain. Energy Rev. 2017, 76, 645-672. [CrossRef]

2. Kazem, H.A. Evaluation and analysis of water-based photovoltaic/thermal (PV/T) system. Case Stud. Therm. Eng. 2019, 13, 100401. [CrossRef]

3. Buonomano, A.; Calise, F.; Vicidomini, M. Design, simulation and experimental investigation of a solar system based on PV panels and PVT collectors. Energies 2016, 9, 497. [CrossRef]

4. Kazem, H.A.; Al-Waeli, A.H.; Chaichan, M.T.; Al-Waeli, K.H.; Al-Aasam, A.B.; Sopian, K. Evaluation and comparison of different flow configurations PVT systems in Oman: A numerical and experimental investigation. Sol. Energy 2020, 208, 58-88. [CrossRef] 
5. Bakari, R. Heat transfer optimization in air flat plate solar collectors integrated with baffles. J. Power Energy Eng. 2018, 6, 70-84. [CrossRef]

6. Hegazy, A.A. Comparative study of the performances of four photovoltaic/thermal solar air collectors. Energy Convers. Manag. 2000, 41, 861-881. [CrossRef]

7. Pottler, K.; Sippel, C.M.; Beck, A.; Fricke, J. Optimized finned absorber geometries for solar air heating collectors. Sol. Energy 1999, 67, 35-52. [CrossRef]

8. Riffat, S.B.; Cuce, E. A review on hybrid photovoltaic/thermal collectors and systems. Int. J. Low-Carbon Technol. 2011, 6, $212-241$. [CrossRef]

9. Tyagi, V.V.; Kaushik, S.C.; Tyagi, S.K. Advancement in solar photovoltaic/thermal (PV/T) hybrid collector technology. Renew. Sustain. Energy Rev. 2012, 16, 1383-1398. [CrossRef]

10. Sarafraz, M.M.; Safaei, M.R.; Leon, A.S.; Tlili, I.; Khan, I.; Tian, Z.; Goodarzil, M.; Arjomandi, M. Experimental investigation on thermal performance of a PV/T-PCM (Photovoltaic/Thermal) system cooling with a PCM and nanofluid. Energies 2019, 12, 2572. [CrossRef]

11. Sarafraz, M.M.; Goodarzi, M.; Tlili, I.; Alkanhal, T.A.; Arjomandi, M. Thermodynamic potential of a high-concentration hybrid photovoltaic/thermal plant for co-production of steam and electricity. J. Therm. Anal. Calorim. 2020, 1-10. [CrossRef]

12. Boutina, L.A.; Khelifa, A.; Touafek, K.; Lebbi, M.; Baissi, M.T. Improvement of PVT air-cooling by the integration of a chimney tower (CT/PVT). Appl. Therm. Eng. 2018, 129, 1181-1188. [CrossRef]

13. Tiwari, S.; Agrawal, S.; Tiwari, G.N. PVT air collector integrated greenhouse dryers. Renew. Sustain. Energy Rev. 2018, 90, 142-159. [CrossRef]

14. Fan, W.; Kokogiannakis, G.; Ma, Z. Optimisation of life cycle performance of a double-pass photovoltaic thermal-solar air heater with heat pipes. Renew. Energy 2019, 138, 90-105. [CrossRef]

15. Kim, J.-H.; Park, S.-H.; Kang, J.-G.; Kim, J.-T. Experimental performance of heating system with building-integrated PVT (BIPVT) collector. Energy Procedia 2014, 48, 1374-1384. [CrossRef]

16. Abdullah, A.L.; Misha, S.; Tamaldin, N.; Rosli, M.A.M.; Sachit, F.A. Photovoltaic thermal/solar (PVT) collector (PVT) system based on fluid absorber design: A review. J. Adv. Res. Fluid Mech. Therm. Sci. 2018, 48, 196-208.

17. Singh, H.P.; Jain, A.; Singh, A.; Arora, S. Influence of absorber plate shape factor and mass flow rate on the performance of the PVT system. Appl. Therm. Eng. 2019, 156, 692-701. [CrossRef]

18. Hu, J.; Sun, X.; Xu, J.; Li, Z. Numerical analysis of mechanical ventilation solar air collector with internal baffles. Energy Build. 2013, 62, 230-238. [CrossRef]

19. Kim, S.-M.; Kim, J.-H.; Kim, J.-T. Experimental study on the thermal and electrical characteristics of an air-based photovoltaic thermal collector. Energies 2019, 12, 2661. [CrossRef]

20. International Electrotechnical Commission. Crystalline Silicon Terrestrial Photovoltaic (PV) Module—Design Qualification and Type Approval; IEC: London, UK, 2016. 